\title{
Study on Necessity to Cultivate English Pragmatic Competence of Non-English Majors
}

\author{
Huaru Chen \\ Foreign Language School, Linyi University \\ Linyi 276005, Shandong, China \\ E-mail:chenhuaru81@163.com
}

Received: April 11, $2011 \quad$ Accepted: April 29, $2011 \quad$ doi:10.5539/ass.v7n9p235

\begin{abstract}
English pragmatic competence is one of the major components of English communicative competence, but it has not aroused enough attention in college English teaching. From a survey on the status quo of English pragmatic competence among non-English undergraduate majors, this article explored and discussed necessity and feasibility to cultivate English pragmatic competence of students in college English teaching.
\end{abstract}

Keywords: Pragmatic competence, Pragmatic failure, Communicative competence, Non-English majors

\section{Introduction}

With swift development of economic globalization, the type of talents required by the society is also taking subtle changes. Single technology-oriented talents are no longer recognized by the society, while diversified technology-oriented talents who are proficient both in professional knowledge and application of English are in great demand. This sort of talents has become gradually the major role on the stage of world economy and technology. Therefore, it seems extremely important to cultivate the English pragmatic competence of non-English undergraduate majors. However, some general undergraduate universities and colleges still remain at the level of form in terms of cultivation of English pragmatic competence of non-English majors, since they believe that English pragmatic competence is dispensable for non-English majors. As a consequence, in college English teaching, trainings on students' pragmatic competence are limited and students' pragmatic competence can't get effectively improved, which finally leads to difficult employment of university students after their graduation. The author attempted to start from a survey on the status quo of the English pragmatic competence of non-English undergraduate majors in general undergraduate universities and colleges and explored and discussed necessity and feasibility of cultivation of English pragmatic competence of non-English majors.

\section{Theoretical foundation}

\subsection{What is pragmatic competence?}

The word "pragmatics" was firstly put forward by the US Logician Morris in 1937. Morris definitely pointed out that, pragmatics was proposed to study relations between symbols and symbol interpreters. According to him, symbols were animate, while pragmatics was a field to study all psychological, physiological and social phenomena that happened with the effect of symbols (Morris, C.W., 1937). Thus, during that period, areas involved by pragmatics were quite extensive, including psychology, philosophy and cognitive science, etc.

However, the word "pragmatic competence" has not had a long history in the area of second language acquisition. Hymes (1971) proposed the idea that competence was knowledge and skill and classified communicative competence into four parts, namely, possibility, feasibility, appropriateness and performance (Hymes, D., 1971). Canal \& Swaine (1980) generalized communicative competence accordingly as grammatical competence, social linguistic competence and strategic competence (Canal, M \& Swain, 1980). With continuous development of deepening of the study, Widdowson (1989) again generalized communicative competence as the two major aspects of grammatical competence and pragmatic competence (Widdowson, H.G., 1978). Thus, it can be seen that, the pragmatic competence proposed by Widdowson included social linguistic competence and strategic competence, and occupied an important position in linguistic communicative competence. Then, what on earth is pragmatic competence? Pragmatic competence can be interpreted as the competence to employ language for appropriate communication, which can be simplified as the two major aspects of expression and 
comprehension (He Ziran, 1997). That is to say, pragmatic competence is the competence of speakers to employ appropriate and accurate language to express their thought and apprehend the meaning and intention of what the other speaker says.

\subsection{Types of pragmatic failure}

In pragmatic linguistic failure, learners apply mechanically the pragmatic meaning of certain words or expressions with their own national language into their interpretation of a foreign language, or the foreign language they learn does not conform with the linguistic habits of the native speakers of this foreign language (He Ziran, 1997). In their intercultural communication, people often need to appropriately use the target language to convey their intention or thought to the others according to the linguistic environment which they are in. In pragmatic failure, affected by the habit of using their mother tongue, people often apply mechanically the thinking mode in their mother tongue into the target language in their intercultural communication with the target language, which results in their inability to correctly comprehend the actual intention of the other party and to appropriately express their speech intention, which is termed as linguistic usage failure. Pragmatic failure is mainly caused by ambiguous understanding of the cultural knowledge of the target language.

According to British Linguist Thomas (1983), pragmatic failure could be generally classified into two types, namely, linguistic pragmatic failure and social pragmatic failure (Thomas, J., 1983) . Linguistic pragmatic failure refers to expression means which do not conform with the linguistic habits and linguistic behavioral strategy of the target language, which is caused by learners' applying mechanically the linguistic habits in their mother tongue when there exist systematic differences between the target language (foreign language) and the mother tongue of the learners in terms of linguistic structure. This kind of pragmatic failure is usually caused by teaching failure or direct translation of the mother tongue. Social pragmatic failure refers to expression means that do not conform with the pragmatic principles of the target language, which is caused by ignorance of the cultural background knowledge in the target language among learners. These two types of pragmatic failures can both be improved and corrected by means of foreign language teaching.

\subsection{Significance to grasp the English pragmatic competence}

According to interpretation of Widdowson (1989) in linguistic communicative competence, namely, the communicative competence including the two aspects of grammatical competence and pragmatic competence, it is not difficult for us to find that correctness of language (grammatical competence) and appropriateness (pragmatic competence) both play an important role in linguistic communication. Nevertheless, appropriateness of language seems especially important in actual linguistic communication, because grammar mistake in communication with a second language can be explained to be nothing more than be non-proficient of the speaker in the second language, whereas inappropriate expressions with the second language in actual communication can be deemed as defective quality of the speaker or unfriendly performance of the speaker, especially in the situation when the speaker is able to speak the second language quite fluently, which might lead to communicative failure. Thomas (1983) believed that pragmatic failure was an important source for intercultural communication impediment (Thomas, J., 1983). Therefore, it seems quite important to pay attention to cultivating students' pragmatic competence in English teaching. However, in college English teaching in quite a large number of general undergraduate universities and colleges, acquisition of grammatical knowledge is still overemphasized, while cultivation of students' pragmatic competence is still neglected. The author of this article made a random sampling survey on the English pragmatic competence of students in a general undergraduate university, and the research result was worrying.

\section{Survey and analysis}

\subsection{Respondents}

The respondents we selected were non-English undergraduate freshmen and sophomores in a general undergraduate university in Shandong Province. The reason why we chose students of these two grades was that only freshmen and sophomores of non-English majors in Shandong Province are allowed to select college English course, whereas students of the other grades were not allowed to take this course. Since students of these two grades were receiving college English education, the frequency of their usage of English was relatively higher than students of other grades and their competence of application of English was also relatively better. Selection of students of these two grades was mainly aimed to grasp universality of the status quo of the English pragmatic competence among non-English majors. 


\subsection{Result of survey and analysis of the result}

\section{Insert Table 1 Here}

From Table 2, it can be found that, although the test performance of pragmatic competence among students who entered the university in 2005 was slightly better than students entering the university in 2006, students with a score above 85 only accounted for $15.2 \%$, whereas students with a score below 60 accounted for $23.1 \%$. Generally speaking, the English pragmatic competence of students in this university was still at a medium-and-lower level. In order to further understand causes for pragmatic failure among university students, the author made a detailed study on the testing answer of students. Research result was shown in Table 2.

\section{Insert Table 2 Here}

From Table 2, it can be found that, pragmatic failure caused by ignorance of English habits accounted for $42 \%$, whereas pragmatic failure that was caused by ignorance of the linguistic and cultural background of English speaking countries accounted for $58 \%$. In terms of causes for failure, there was no significant distinction between the freshmen and sophomores. Thus, it can be found that, in college English teaching, teachers have not had enough teaching of English cultural background in the process of college English teaching, and their cultivation of students' pragmatic competence still remains at the level of form and has not been put into practice.

\section{Discussion}

In "College English Curriculum Requirements" that was promulgated in 2004, Ministry of Education definitely stipulated that, "the target of college English teaching is to cultivate the overall English application competence of university students, especially their listening and speaking competence so as to enable them to use English for effective oral and written communication of information in their work and social intercourse in the future." Six years later, when the author made a survey, the result showed that, the English pragmatic competence of non-English majors in general undergraduate universities is still not optimistic. Considering the entire survey result, only $12.2 \%$ of university students had a score above 85 in the test of pragmatic competence, whereas the number of students with a score below 60 accounted for $25.6 \%$ of the total number of students. This indicates that, the English pragmatic competence of non-English undergraduate majors in general undergraduate universities is still an important subject that is in urgent need to be resolved.

From an objective perspective, the ages of freshmen and sophomores in Chinese universities are generally concentrated within 18 to 20 , and during this period students have already had strong cognitive competence and their internal speech in the process of English learning is manifested as characteristics of their mother tongue. Since they have in their mind had the thinking habit of their mother tongue, affected by the subconscious constraints and cultural dependence of the mother tongue, it is a frequent phenomenon that English learners seek for an expression means in their communication in English that corresponds with the mother tongue, starting out subconsciously from the culture of their mother tongue, which leads to pragmatic linguistic failure, termed as pragmatic transfer. This is reflected in selection of appellation, greetings, invitation, compliments, modesty words, leave-taking, apology words and euphemism, etc. However, if we analyze college English classroom teaching from a subjective initiative perspective, then it is not difficult for us to discover that another important factor that causes students' pragmatic failure lies in English classroom teaching. In English teaching, English teachers do not focus on teaching of English cultural background knowledge, but blindly pay attention to cultivation of students' pronunciation, vocabulary and grammatical competence, ignoring introduction to English language and culture background knowledge and cultivation of actual communicative competence. Although students cultivated under this sort of teaching model may have good performance in exams and the sentences they say almost have no grammatical mistakes, actually, lots of pragmatic failures exist, so the actual purpose of communication in English has no way to be achieved. This, to some extent, is called "high score and low ability". The US Linguist Edward Sapir ever said "There is always something behind language, and language can't go without culture. The so-called culture is the sum of habits and beliefs that are passed down in the society, which is able to determine our living organization." People who speak different languages may have misunderstandings of each other in their conversations as a result of cultural differences, even if the language they speak is accurate with no grammatical mistake. For different people, the same phrase or the same expression may have different meanings.

For example, there was such a subject during this test:

(When you meet your teacher whose name is $\mathrm{Li}$ in the morning), you'll say:

Good morning, 
82.2\% students had such an answer: Good morning, teacher / teacher Li. This pragmatic failure was caused by simply indiscriminate application of expression means in the mother tongue.

Furthermore, we can also find that quite a large number of students bring the Chinese culture into English communication in greetings and leave-taking. During this test, we set up such an occasion, "when you meet with your foreign teacher in the campus, how would you like to make greetings or fall into talk with him/her?" Answers of $80 \%$ students included such sentences, "Where are going?" "What are you going to do?" and "Have you eaten?" As a matter of fact, in actual communication, this kind of problems may get foreign teachers displeased who have come to China for the first time, for they have a feeling in their mind that their privacy has been peeped by others, though Chinese students only intend to express their concern with foreign teachers and even those are nothing more than common words to make greetings with others with no implication at all. This kind of pragmatic failure is caused by excessive and mechanical copy of their native culture. Of course, the foreign teachers might also read the inquiry of "Have you eaten?" as a kind of invitation, mistakenly interpreting it as a hint that you want to invite them to dinner. When saying goodbye to others, Chinese people are accustomed to say "Man zou". Thus, there are some students who would directly translate this expression into English expression "Go slowly and carefully". This sort of Chinese concern and consideration will get no result but to make the foreigners confused and puzzled, since westerners usually just say "Good bye" or "See you".

The pragmatic failure we have talked above belongs to linguistic pragmatic failure, which can totally be overcome through classroom emphasis and repeated exercise. However, in practical teaching, quite a large majority of teachers mistakenly believe that this sort of issues won't affect the general situation which is beneath their notice, resulting in wrong and directed thinking mode of students. Actually, in international communication, westerners are quite pay great attention to their salutations to others, for in their eyes, salutations are affirmation of their identity and status in the society, and wrong salutations will naturally lead to unhappy endings. In addition, westerners concentrate a lot on their personal right of privacy, and they are intolerant if others enquire for the personal age, wage and marriage, etc. On the contrary, all these social elements are relatively transparent in China, which are also subjects that are often mentioned in daily life. Thus, one of the urgent issues to be resolved in intercultural communication is to try to resolve distinctions between Chinese culture and foreign language culture in terms of pragmatic aspect. The root source of pragmatic distinctions actually lies in distinctions in culture. Therefore, in college English teaching, teachers are absolutely forbidden to reduce cultivation of students' English pragmatic competence according to their likes and dislikes.

\section{Conclusion}

Bachman (1999) pointed out, linguistic competence was constituted by the competence to organize language and the pragmatic competence (Bachman, Lyle F., 1999). Thus, improvement of the pragmatic competence and communicative competence accompany with the entire process of language learning. Due to differences in geographical position, natural environment, origin of race, historical transition, religious belief and economic development, each nation has had its own culture to match with its own language. Hence, Ver-schueren said, "Pragmatics is to study linguistic phenomena and usage of language in people's behaviors from the cognitive, social and cultural perspectives." (Verschueren, Jef, 2000) Learning of linguistic knowledge and pragmatic cognition should be developed with an escalating trend in the same direction. In one word, although the English education in China has already achieved a high level, still lots of problems still exist. English teachers ought to be clearly aware that it is of no significance to purely teach English vocabulary, grammar and sentence structure in college English teaching. We have to adjust in time our teachers' teaching principle, enrich their teaching content and integrate effectively the pragmatic teaching into their teaching. Only in this way, can we comply with the basic rules of language teaching and can we cultivate a new type of talents to fit with the development of the times.

\section{References}

Bachman, Lyle F. (1999). Fundamental Considerations in Language Testing. Shanghai: Shanghai Foreign Language Education Press.

Canal, M \& Swain. (1980). Theoretical Bases of Communicative Approaches to Second Language Teaching and Testing . Applied Linguistics, 1/1.

He, Ziran. (1997). Pragmatics and English Learning. Shanghai: Shanghai Foreign Language Education Press.

Hymes, D. (1971). Competence and Performance in Linguistic theory. In R. Huxley \&E. Ingram (Eds.), Language Acquisition :Models and Methods. London: Academic Press.

Morris, C.W. (1937). Logical Positivism, Pragmatism and Scientific Empiricism. Paris: Hermannetlie. 
Thomas, J. (1983). Cross-cultural Pragmatic Failure. Applied Linguistics, 2/4.

Verschueren, Jef. (2000). Understanding Pragmatics. Foreign Language Teaching and Research Press, Edward Arnold (Publishers) Limited.

Widdowson, H.G. (1978). Teaching Language as Communication. Oxford: Oxford University Press.

Table 1. Test result of pragmatic competence

\begin{tabular}{|l|l|l|l|l|}
\hline \multicolumn{1}{|c|}{ Score } & $100-85$ & $84-75$ & $74-60$ & Below 60 \\
\hline 2005 & & & & \\
\hline 2006 & 15 & 23 & 37 & 24 \\
\hline Total & 9 & 20 & 42 & 27 \\
\hline
\end{tabular}

Table 2. Causes for pragmatic failure

\begin{tabular}{|c|c|c|}
\hline $\begin{array}{l}\text { Number } \\
\text { of students } \\
\text { (Percentage) }\end{array}$ & $\begin{array}{c}\text { Linguistic pragmatic } \\
\text { failure }\end{array}$ & Social pragmatic failure \\
\hline 2005 & $42.7 \%$ & $57.3 \%$ \\
\hline 2006 & $41.3 \%$ & $58.7 \%$ \\
\hline Total & $42 \%$ & $58 \%$ \\
\hline
\end{tabular}

